\title{
PELATIHAN DARING PEMANFAATAN JERAMI PADI SEBAGAI MEDIA TUMBUH PADA BUDIDAYA JAMUR MERANG
}

\author{
Fita Afifaturrosyidah ${ }^{1)}$ Juliani $^{2)}$ Richa Nur Habibah $^{\text {3) }}$ \\ Fikri Prianggono ${ }^{4)}$ Tatang Sopandi ${ }^{5)^{*}}$ \\ 1,2,3,4,5Fakultas MIPA, Universitas PGRI Adi Buana Surabaya \\ *Email : tatang.sopandi.1963@gmail.com
}

\begin{abstract}
ABSTRAK
Desa Grinting Kecamatan Tulangan Kabupaten Sidoarjo merupakan suatu wilayah pertanian padi yang pada masim panen ketersediaan jerami padi melimpah dan seringkali tidak dimanfaatkan untuk menghasilkan nilai tambah secara ekonomi. Petani cenderung membakar jerami padi dan sering menimbulkan polusi udara lingkungan sekitar. Usaha budidaya jamur merang menggunakan jerami padi sebagai media tumbuh jamur merang merupakan salah satu pilihan yang layak dilakukan untuk mengatasi masalah tersebut. Namun, masyarakat desa Grinting belum mempunyai pengetahuan dan pamahaman yang cukup untuk melakukan usaha budidaya jamur merang. Pelatihan ini bertujuan untuk meningkatkan pengetahuan, pamahaman dan minat masyarakat di desa Grinting untuk melakukan usaha budidaya jamur merang menggunakan jerami padi sebagai media tumbuh. Pelatihan telah dilakukan secara daring menggunakan aplikasi zoom dan Whatapp selama 2 bulan. Karang Taruna dan anggota GAPOKTAN menjadi mitra sasaran untuk pelatihan daring ini. Selama pelatihan, mitra sasaran sangat aktif dan antusias mengikuti pelatihan, melakukan diskusi dan tanya jawab. Pelatihan daring ini berhasil meningkatkan pengetahuan, pemahaman dan minat usaha mitra sasaran untuk melakukan budidaya jamur merang menggunakan jerami padi sebagai media tumbuh. Hasil nyata berupa perubahan prilaku tampak nyata pada mitra sasaran dan terdapat anggota yang telah melakukan praktik mandiri pembuatan media tumbuh jamur merang menggunakan jerami padi.
\end{abstract}

Kata kunci: Desa Grinting, jamur merang, jerami padi, media tumbuh

\section{TRAINING THE UTILIZATION OF RICE STRAW AS A GROWING MEDIA IN STRAW MUSHROOM CULTIVATION}

\begin{abstract}
Desa Grinting, Kecamatan Tulangan, Kabupaten Sidoarjo is a rice farming area which in the harvest season is abundant and the rice straw is not used to generate added value economically. Farmers tend to be rice straw and often pollute the surrounding air. Cultivation of straw mushroom using straw as a growing medium is a viable option to overcome this problem. However, the people of Desa Grinting do not yet have sufficient knowledge and understanding to carry out a mushroom cultivation business. This training aims to increase the knowledge, understanding and interest of the people in Desa Grinting to carry out a straw mushroom cultivation business using rice straw as a growing medium.
\end{abstract}


Training has been conducted using zoom and Whatapp applications for 2 months. The Youth Organization and GAPOKTAN members became target partners for this online training. During the training, the target partners were very active and enthusiastic about participating in the training, holding discussions and questions and answers. This courage training succeeded in increasing the knowledge, understanding and business interest of the target partners in cultivating edible mushrooms using straw as a growing medium. The real results in the form of behavior change were evident in the target partners and there were members who had done independent practice of making plant media using rice straw.

Keywords: Desa Grinting, straw mushroom, rice straw, growing media

\section{PENDAHULUAN}

Desa Grinting, Kecamatan Tulangan, Kabupaten Sidoarjo, memiliki luas wilayah 132,25 $\mathrm{km}^{2}$ dengan jumlah penduduk sebanyak 3.693 jiwa (IDM, 2019). Kondisi Geografis Desa Grinting terdiri dari hamparan dataran tanah darat yang dilewati aliran sungai untuk mengairi kebutuhan pertanian tanaman padi dan kebun. Berdasarkan data kantor Kepala Desa Grinting Tahun 2019 luas tanah sawah sebesar 97.24 Ha dan tanah kering 31.17 Ha. Sebagian besar bermata pencaharian sebagai petani, buruh tani dan sisanya ada yang bekerja sebagai buruh pabrik. Petani sebanyak 464 jiwa dan buruh tani sebanyak 578 jiwa yang secara ekonomi masih dalam taraf menengah ke bawah dengan penghasilan tidak menentu dan rata-rata penghasilan kurang dari Rp.950.000,00 per bulan.

Pandemi Covid 19 sangat berdampak terhadap semua sektor kehidupan manusia, termasuk sektor pertanian di berbagai negara. Pandemi ini berdampak pada penurunan jumlah tenaga kerja, gangguan rantai pasokan, penurunan penjualan produk pertanian, larangan ekspor dan penutupan restoran di Malaysia (Juwaidah, 2020). Peningkatan harga input, gangguan rantai pasokan, dan penuruan permintaan produk pertanian tertentu terutama produk tersier merupakan dampak Covid-19 yang dirasakan oleh petani di Indonesia (Rozaki, 2020). Selain itu, himbauan tetap di rumah juga berpengaruh terhadap aktivitas usaha petani yang pada gilirannya akan berdampak pada penurunan produksi pertanian. Kegiatan-kegiatan yang bernilai ekonomi dan dilakukan secara mandiri di lahan-lahan pekarangan dengan memanfaatkan sumber daya lokal merupakan salah satu alternatif untuk mengurangi dampak pendemi terhadap sektor pertanian.

Budidaya jamur merang merupakan salah satu pilihan yang layak untuk dilakukan dan dikembangkan oleh petani termasuk 
pada masa pendemi. Permintaan jamur merang di Indonesia terus meningkat, namun produksi terbatas sehingga nilai ekonomi jamur merang semakin meningkat (Sinaga, 2009). Teknologi budidaya jamur merang mudah diadaptasi dapat dipelihara dengan media tumbuh limbah pertanian dengan waktu pemeliharaan sampai panen singkat sekitar 10-14 hari.

Petani di desa Grinting belum pernah melakukan budidaya jamur merang karena keterbatasan pengetahuan, pemahaman dan keterampilan. Pelatihan ini bertujuan untuk meningkatkan pengetahuan, pemahaman dan keterampilan budidaya jamur merang pada petani di desa Grinting, Kecamatan Tulangan, Kabupaten Sidoarjo dengan memperhatikan protokol kesehatan covid-19.

\section{KAJIAN LITERATUR}

Pertanian jamur merupakan salah satu pilihan yang layak digunakan untuk peningkatan pertanian keberlanjutan, ketahanan dan keanekaragaman pangan serta mengembangkan sumber pendapatan yang lebih andal terutama untuk petani skala kecil (Rosmiza et al., 2016). Budidaya jamur merupakan bioteknologi yang efisien dan ekonomis (Bradley, 2013). Input produksi untuk budidaya jamur rendah, teknologi produksi mudah, dapat dilakukan pada lahan terbatas dengan investasi yang diperlukan rendah pada lahan dengan residu pertanian tersedia secara melimpah (Bradley, 2013). Budidaya jamur secara langsung dapat meningkatkan mata pencaharian melalui kontribusi terhadap ekonomi, nutrisi dan pengobatan (Marshall dan Nair, 2009). Usaha budidaya jamur dapat berdampak terhadap mata pencaharian dan penanggulangan kemiskinan sangat luas (Rosmiza et al., 2016).

Budidaya jamur dapat menjadi kegiatan yang layak dan menarik untuk memperoleh pendapatan dan usaha paruh waktu untuk petani pedesaan dan penduduk kota karena tidak membutuhkan banyak lahan luas dengan investasi modal dan penggunaan tenaga kerja yang rendah (Zhang et al., 2014). Usaha jamur juga dapat meningkatkan pemberdayaan petani dan kemandirian finansial (Zhang et al., 2014). Di beberapa negara Asia seperti Cina dan Vietnam, budidaya jamur terintegrasi erat dengan pertanian padi. Setelah panen, jerami padi digunakan sebagai media untuk menumbuhkan jamur merang (Marshall dan Nair, 2009).

Jamur merang (Volvariella volvacea) dikenal sebagai jamur jerami atau jamur merang merupakan salah satu jenis jamur merang yang dibudidayakan di seluruh Asia Timur dan Tenggara (Sudha et al. 2008). Budidaya jamur merang dapat 
meningkatkan nilai tambah jerami padi dan meningkatkan pendapatan petani miskin di negara berkembang (Imtiaj dan Rahman 2008; Shakil et al. 2014; Zhang et al. 2014). Jamur merang merupakan salah satu jamur yang paling banyak dibudidaya (Walde et al.2006) dan menempati urutan jamur penting karena mempunyai rasa yang enak (Ramkumar et al.2012; Thiribhuvanamala et al. 2012), dengan waktu produksi yang lebih pendek dibandingkan dengan species jamur lain species (Rajapakse, 2011). Produksi jamur merang menempati urutan keenam di antara jamur yang dapat dimakan, dengan proporsi produksi sekitar 5-6\% dari produksi jamur di dunia (Ahlawat et al. 2011).

Jamur merang mengandung protein, kalium, dan fosfor yang tinggi (Ahlawat dan Tewari 2007), bebas garam dengan kandungan alkalinitas, lemak, dan kolesterol rendah. Jamur merang juga mengandung selenium (Solovyev et al. 2018) dan niacin (Ahlawat dan Tewari 2007; Eguchi et al. 2015), yang merupakan dua senyawa esensial dalam sistem kekebalan tubuh dan tiroid yang berperan dalam pencegahan kanker (Hobbs, 1995). Kandungan serat jamur merang penting untuk fungsi fisiologis dalam saluran pencernaan (Manzi et al.
2001). Selain itu, jamur merang memiliki aktivitas antimikroba yang signifikan (Chandra dan Chaubey 2017) serta menyediakan sumber polipeptida, terpene, dan steroid yang baik (Shwetha dan Sudha 2012). Jamur merang juga mengandung senyawa fenolik, seperti flavonoid, asam fenolik, dan tanin yang berkontribusi terhadap sifat antioksidannya yang tinggi (Hung dan Nhi 2012). Sumber antioksidan lain dari jamur merang adalah katalase, superoksida dismutase, glutathione peroksidase, peroksidase, glutathione-Stransferase, dan glutathione reduktase (Ramkumar et al. 2012). Jamur merang dikenal sebagai makanan sehat (Belewu dan Belewu 2005; Feeney et al. 2014). Jamur merang RSM dianggap sebagai salah satu jamur yang paling mudah dibudidayakan karena masa produksinya singkat (Zikriyani et al. 2018). Jamur merang dapat tumbuh di daerah bercuaca hangat, biasanya di daerah tropis dan subtropic dengan suhu optimal $30-35^{\circ} \mathrm{C}$ untuk pertumbuhan miselium dan 28$30^{\circ} \mathrm{C}$ untuk produksi tubuh buah (LeDuy-Thang, 2006). Kelembaban relatif 70-90\% paling baik untuk pertumbuhan jamur merang (Biswas dan Layak, 2014) dengan $\mathrm{pH}$ 6,5. Nilai $\mathrm{pH}$ yang lebih tinggi dari 6,5 menghambat pertumbuhan miselia (Akinyele dan Adetuyi, 2005). 
Jenis jamur ini tumbuh baik pada berbagai substrat selulosa, seperti jerami padi, jerami gandum, ampas tebu, daun pisang, eceng gondok, dan lain-lain.

\section{METODE PELAKSANAAN}

Kegiatan pelatihan pemanfaatan jerami padi sebagai media tumbuh pada budidaya jamur merang di Desa Grinting Kecamatan Tulangan Kabupaten Sidoarjo telah dilaksanakan mulai tanggal 12 Agustus 2020 sampai dengan 27 September 2020. Metode pelaksanaan kegiatan pelatihan seluruhnya dilakukan secara daring terdiri dari tahap persiapan, pelaksanaan, dan pendampingan. Kegiatan persiapan meliputi (1) survei lapangan, (2) pembuatan proposal dan penyelesaian administrasi perizinan, (3) pendataan dan seleksi calon peserta dari mitra serta (4) pembuatan jadwal dan konsep daring aplikasi Whatspp dan Zoom meeting.

Kegiatan pelatihan dilaksanakan setelah semua perijinan sudah selesai. Kegiatan pelatihan dirancang agar peserta nyaman, menikmati serta dapat saling berinteraksi dan bertukar pikiran antar warga dengan tim pelaksana secara daring. Pelaksanaan kegiatan meliputi (1) sosialisasi, (2) pra-tes, (3) pelatihan, (4) post-tes, dan (5) pendampingan.

Tahap sosialisasi mencakup pengenalan dan gambaran umum teknik pelatihan serta membuat kesepakatan-kesepakatan jadwal pelaksanaan pelatihan. Tahap sosialisasi telah dilaksanakan pada tanggal 16 Agustus 2020.

Tahap pra-tes telah dilaksanakan pada tanggal 22 Agustus 2020 menggunakan google form dengan model pertanyaan tertutup. Pra-tes dilakuan untuk mengetahui pengetahuan, pemahaman dan minat mitra sasaran terhadap usaha budidaya jamur merang dengan memanfaatkan jerami padi sebagai media tumbuh.

Tahap pelaksanaan pelatihan daring dilaksanakan selama 5 minggu mulai dari tanggal 23 Agustus 2020 sampai dengan 27 September 2020. Pelatihan daring dilakukan dengan memberikan tutorial teknik budidaya jamur merang menggunakan jerami padi sebagai media tumbuh. Pelatihan daring pelatihan mencakup:

a. pengenalan kegunaan dan fungsi masing-masing peralatan dan bahan

b. pembuatan media tumbuh jamur merang dari jerami padi

c. perakitan kumbung tempat budidaya jamur merang

d. penanaman jamur merang pada media e. pemanenan dan pemasaran jamur merang

Tahap post-tes bertujuan untuk mengetahui perubahan pengetahuan, 
pemahaman dan minat masyarakat sasaran terhadap budidaya jamur merang setelah pelatihan. Post-test telah dilakukan pada tanggal 27 September 2020 menggunakan google form dengan model pertanyaan tertutup.

Tahap pendampingan dilakukan untuk mitra sasaran yang melakukan praktik secara mandiri setelah pelatihan. Pendampingan bertujuan sebagai monitoring dan melihat perkembangan program yang dilakukan melalui diskusi kelompok dalam aplikasi Whatsapp.

\section{HASIL DAN PEMBAHASAN}

\section{Kegiatan Sosialisasi}

Sosialisasi program pelatihan secara daring melalui grup Whatsapp dan Zoom diikuti oleh 10 orang anggota mitra sasaran dan 4 orang tim PKM-M Universitas PGRI Adi Buana, Surabaya. Karang Taruna dan Gabungan Kelompok Tani (GAPOKTAN) merupakan dua kelompok mitra yang menjadi sasaran PKM-M ini. Namun karena sebagian besar anggota GAPOKTAN tidak memiliki alat komunikasi (smartphone atau laptop) sehingga pelatihan daring sulit dilakukan oleh sebagian besar anggota. Setelah dilakukan sosialisasi dan pendekatan, terdapat 8 orang anggota Karang Taruna dan 2 orang anggota GAPOKTAN yang dapat mengikuti pelatihan secara daring. Anggota mitra sasaran menerima dan bersedia meluangkan waktunya untuk menerima pelatihan yang dilakukan secara daring.

\section{Pelaksanaan pelatihan}

Mitra sasaran pada setiap pemberian materi pelatihan pemberian materi melalui pemberian video tutorial (Gambar 1), zoom meet (Gambar 2) dan melalui diskusi kelompok whatsapp (Gambar 3) sangat aktif.

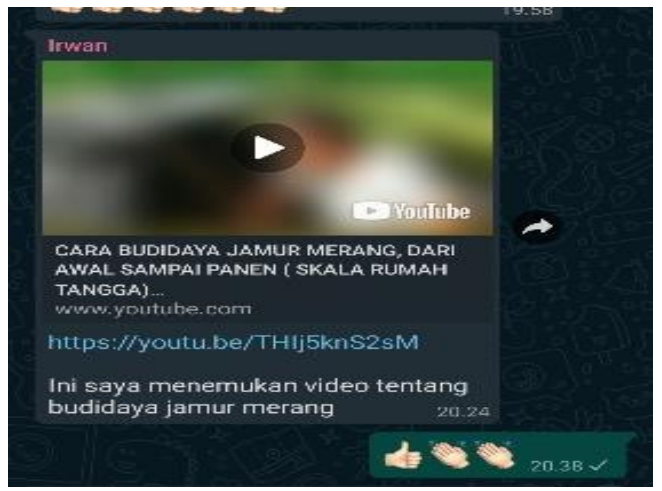

Gambar 1. Pelatihan budidaya jamur merang secara daring melalui aplikasi youtube.

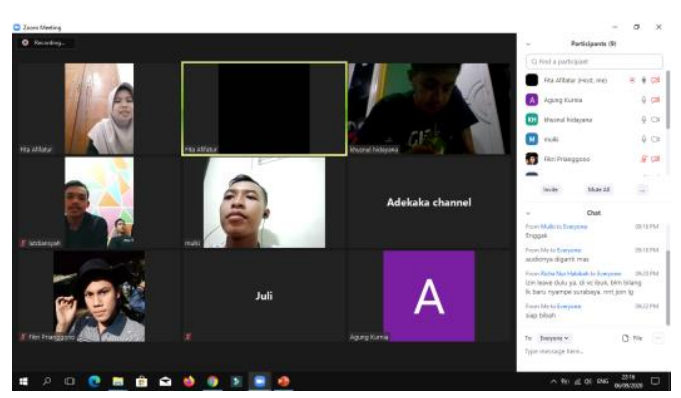

Gambar 2. Pelatihan budidaya jamur merang secara daring melalui aplikasi Zoom meet. 


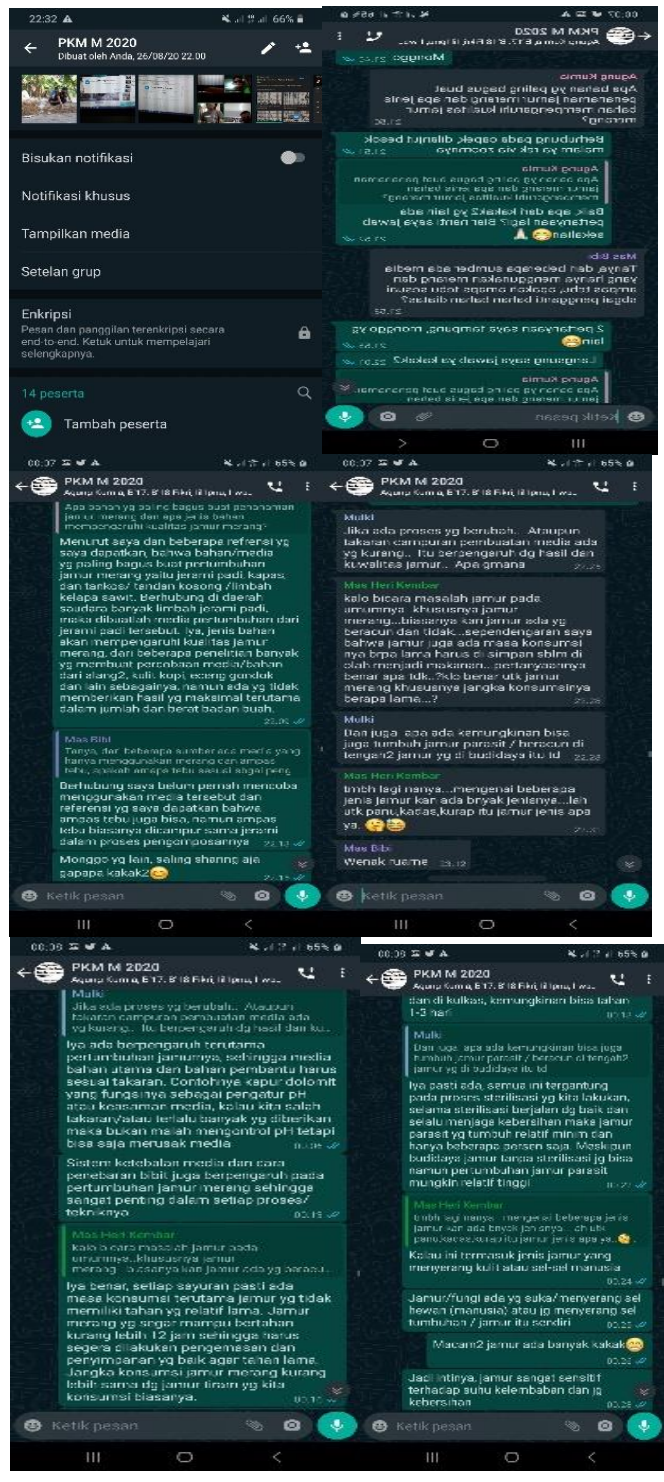

Gambar 3. Sesi diskuai dan tanya jawab mitra sasaran dengan tim PKM-M melalui whatApp grup

Selama diskusi daring menunjukkan bahwa budidaya jamur merang menggunakan jerami padi sebagai media tumbuh merupakan pengetahuan dan pengalaman baru untuk mitra. Mitra sasaran sangat antusias mencari informasi secara mandiri tentang budidaya jamur merang dengan menunjukkan beberapa video yang diperoleh dan dibagikan dalam kelompok diskusi. Pencarian informasi tersebut dilakukan secara mandiri selama masa pelatihan untuk selanjutnya digunakan sebagai bahan diskusi dengan Tim PKM-M.

Mitra sasaran sebagian besar faham dengan materi yang disampaikan pada pelatihan pengenalan alat dan budidaya jamur merang. Alat dan bahan yang digunakan cukup mudah didapatkan dengan harga-harganya cukup terjangkau. Mitra juga menganggap bahwa jerami padi dapat mempunyai nilai tambah secara ekonomi jika dimanfaatkan sebagai media tumbuh jamur merang.

Mitra sasaran sangat memahami proses pembuatan media tumbuh jamur dari jerami padi setelah diberi pelatihan dengan materi pembutan media tumbuh jamur melalui proses. Mitra sasaran menganggap bahwa pembuatan media tumbuh jamur merang cukup mudah dilakukan dengan bahan yang mudah yaitu jerami padi, dedak bekatul, kapur dolomit, urea dan kotoran ayam. Proses pembuatan media tumbuh jamur merang menggunakan jerami padi telah dipraktekan oleh salah seorang anggota seperti yang terlihat pada gambar 4 . 


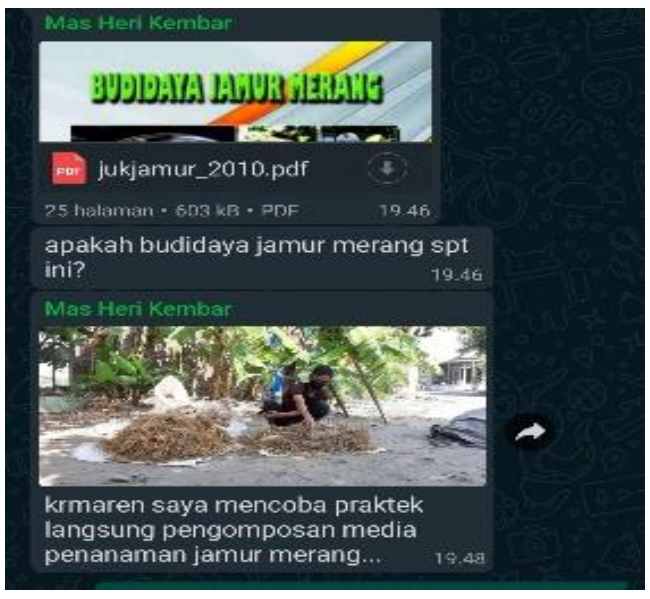

Gambar 4. Praktik pembuatan media tumbuh jamur merang menggunakan jerami padi yang dilakukan mitra secara mandiri.

Kumbung atau rumah jamur salah satu unsur terpenting dalam budidaya jamur merang. Mitra sasaran sangat aktif dan antusias dalam sesi pelatihan perakitan kumbung jamur merang. Mitra berpendapat bahwa kumbung jamur dapat dibuat secara sederhana dan dalam skala kecil dengan harga yang murah. Namun, proses sterilisasi kumbung memerlukan waktu cukup lama sehingga perlu pendampingan yang lebih intensif.

Mitra sasaran pada sesi pelatihan penanaman jamur merang menganggap cukup sulit untuk dilakukan secara mandiri, Mitra sasaran meminta untuk melakukan pendampingan lebih intensif dan mengagendakan kegiatan lanjutan.

Pelatihan dengan materi cara panen, pascapanen dan analisis usahatani jamur merang terlaksana dengan baik dan mitra aktif melakukan diskusi dan tanya jawab. Produk jamur merang baik yang segar maupun yang telah diolah belum ada di daerah sekitar desa Grinting. Mitra mempunyai keinginan untuk praktik dalam skala besar agar menjadi produk unggulan dan percontohan untuk desadesa disekitarnya.

\section{Pengetahuan, pemahaman dan mitra sasaran}

Pengetahuan, pemahaman dan minat mitra sasaran terhadap budidaya jamur merang setelah pelatihan menunjukkan peningkatan. menunjukkan peningkatan pengetahuan, Gambar 5 menyajikan hasil pra-tes dan post-tes mitra sasaran terhadap pelatihan daring pemanfaatan jerami padi sebagai media tumbuh jamur merang. Sebelum pelaksanaan pelatihan (pra-test), sebanyak 32,0\% mitra sasaran telah mengetahui dan $68,0 \%$ belum mengetahui pemanfaatan jerami padi sebagai media budidaya jamur merang. Pengetahuan mitra sasaran meningkat sebesar $56,0 \%$ dari $32 \%$ sebelum pelatihan menjadi $88 \%$ setelah pelatihan (post-test). Sebelum pelatihan, sebanyak $31,4 \%$ mitra sasaran telah memahami dan $68,6 \%$ belum memahami budidaya jamur merang menggunakan jerami padi sebagai media tumbuh. Pemahaman mitra sasaran meningkat sebesar $34,3 \%$ dari $31,4 \%$ 
sebelum pelatihan menjadi $65,7 \%$ setelah pelatihan. Sebelum pelatihan, sebanyak $94,3 \%$ berminat dan $1,8 \%$ tidak berminat untuk melakukan usaha budidaya jamur merang menggunakan jerami padi sebagai media tumbuh. Minat mitra sasaran terhadap usaha budidaya jamur merang menggunakan jerami padi meningkat sebesar $3,7 \%$ dari $94,3 \%$ sebelum pelatihan menjadi $98 \%$ setelah pelatihan.

Hasil pra-tes juga memperlihatkan bahwa masyarakat sasaran sangat berminat untuk melakukan usaha budidaya jamur merang. Namun karena kurangnya pengetahuan dan pemahaman, usaha budidaya jamur merang belum terlaksana oleh masyarakat Desa Grinting.

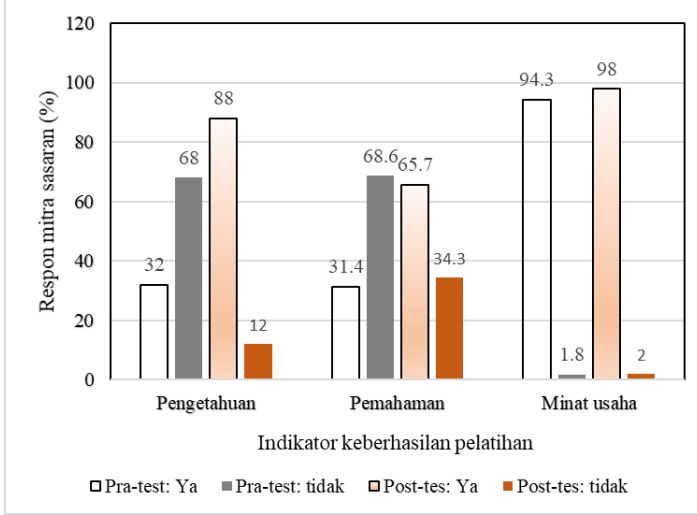

Gambar 5. Respon mitra sasaran sebelum (pre-tes) dan setelah (post-tes) pelatihan pemanfaatan jerami padi sebagai media tumbuh jamur merang.

Hasil yang dicapai dari pelatihan ini berhasil meningkatkan pengetahuan, pemahaman dan minat usaha mitra sasaran merupakan indikator keberhasilan pelatihan. Menurut Harris (2000), tingkat keberhasilan pendidikan dan pelatihan dapat dilihat dari indikator reaksi peserta, perubahan perilaku dan hasil nyata. Reaksi peserta berupa tanggapan peserta terhadap pelaksanaan pelatihan. Hasil nyata berupa kompetensi, pengetahuan dan keterampilan baru yang diperoleh peserta dari program pelatihan. Perubahan perilaku berupa perubahan perilaku pekerjaan peserta setelah pelatihan.

\section{KESIMPULAN}

Pelatihan ini menyimpulkan bahwa pelatihan daring pemanfaatan jerami padi sebagai media tumbuh jamur merang berhasil meningkatkan pengetahuan, pemahaman dan minat usaha mitra sasaran. Perubahan prilaku setelah pelatihan tampak dari mitra sasaran yang telah melakukan praktik secara mandiri. Perubahan prilaku mitra sasaran juga terlihat dari minat untuk melakukan usaha budidaya jamur merang menggunakan jerami padi sebagai media tumbuh. Pelatihan ini menciptakan kegiatan positif yang bernilai ekonomi untuk masyarakat desa Grinting dan membantu pemutusan rantai penyebaran pandemi Covid-19.

\section{UCAPAN TERIMA KASIH}

Seluruh tim dan dosen pembimbing mengucapkan terima kasih Direktorat 
Pembelajaran dan Kemahasiswaan,

Direktorat Jenderal Pendidikan Tinggi,

Kementerian Pendidikan dan Kebudayaan (SIMBELMAWA) yang telah mendanai kegiatan PKM-M Universitas PGRI Adi Buana, tahun 2020. Tim PKM-M juga mengucapkan terima kasih kepada Karang Taruna Grita Mulya dan GAPOKTAN Desa Grinting yang telah bersedia dan bekerjasama dalam pelaksanaan selaku Program PKM-M.

\section{REFERENSI}

Ahlawat, O.P and Tewari, R.P. (2007) Cultivation technology of paddy straw mushroom (Volvariella volvacea). Technical Bulletin. Yugantar Prakashan Pvt. Ltd. WH23, Mayapuri Indl. Area, New Delhi. p 64

Ahlawat, O.P., Singh, R and Kumar, S. (2011) Evaluation of Volvariella volvacea strains for yield and diseases/insect-pests resistance using composted substrate of paddy straw and cotton mill wastes. Indian J Microbiol 51(2):200-205.

Akinyele, B.J and Adetuyi, F.C. (2005) Effect of agrowastes, $\mathrm{pH}$ and temperature variation on the growth of Volvariella volvacea. African J Biotechnol 4(12):1390-1395.

Belewu, M.A and Belewu, K.Y. (2005) Cultivation of mushroom (Volvariella volvacea) on banana leaves. African J Biotechnol 4(12):1401-1403.

Biswas, M.K and Layak, M. (2014) Techniques for increasing the biological efficiency of paddy straw mushroom (Volvariella
Volvacea) in eastern India. Food Sci Technol 2(4):52-57.

Bradley, L. (2013). Oyster Mushroom production: prosperity and problems for a small ngo in Tanzania. The permaculture Research Institute.

Barney, D. L. (2015). Growing mushrooms commercially: Risks and opportunities. [Online] Available:

http://www.cals.uidaho.edu (May 15, 2015).

Chandra, $\mathrm{O}$ and Chaubey, K. (2017) Volvariella volvacea: a paddy straw mushroom having some therapeutic and health prospective importance. World J Pharm Pharm Sci 6(9):1291-1300.

Eguchi, F., Kalaw S.P., Dulay, R.M.R., Miyasawa, N., Yoshimoto, H., Seyama, T and Reyes, R.G. (2015) Nutrient composition and functional activity of different stages in the fruiting body development of Philippine paddy straw mushroom, Volvariella volvacea (Bull.:Fr.) Sing. Adv Environ Biol 9(22):54-65.

Feeney, M.J., Miller, A.M and Roupas, P. (2014) Mushrooms - biologically distinct and nutritionally unique exploring a "third food kingdom". Nutr Today 49(6):301-307.

Harris, M. (2000).Human Resource management.second edition. USA : Harcourt Brace \& Company.

Hobbs, H. (1995) Medicinal mushrooms. Amer IBot 87:821-827.

Hung, P.V and Nhi, N.N.Y. (2012) Nutritional composition and antioxidant capacity of several edible mushrooms grown in the southern Vietnam. Int Food Res J 19(2):611-615.

Indeks Desa Membangun (IDM). (2019). Desa Grinting. Kecamatan Tulangan Kabupatem Sidoarjo. Jawa Timur.

Imtiaj, A and Rahman, S.A. (2008). Economic viability of mushrooms 
cultivation to poverty reduction in Bangladesh. Trop Subtrop Agroecosyst 8:93-99.

Juwaidah. 2020. Agriculture and Food Sectors in Malaysi: Post Covid-19 Pandemic. Disampaikan pada Internasioanl Webinar "Southeast Asian Agriculture Post Covid-19 Pandmei: Current and Future Perspectives" pada 11 Juli 2020.

Le-Duy-Thang (2006). Growing edible mushroom. Ho Chi Minh Agricultural Publisher, $242 \mathrm{p}$.

Marshall, E andNair, N. G. (2009). Make money by growing mushrooms. Food and Agriculture Organization (FAO) of The United Nations: Rome.

Manzi, P., Aguzzi, A and Pizzoferrato, L. (2001). Nutritional value of mushrooms widely consumed in Italy. Food Chem 73(3):321-325.

Rajapakse, P. (2011) New cultivation technology for paddy straw mushroom (Volvariella volvacea). In Proceedings of the 7th International Conference on Mushroom Biology and Mushroom Products (ICMBMP7). 446-451.

Ramkumar, L., Ramanathan, $\mathrm{T}$ and Johnprabagaran, J. (2012). Evaluation of nutrients, trace metals and antioxidant activity in Volvariella volvacea (Bull. Ex. Fr.) Sing. Emir J Food Agric 24(2):113-119.

Rosmiza, M.Z. (2016). Prospects for Increasing Commercial Mushroom Production in Malaysia: Challenges and Opportunities Mediterranean Journal of Social Sciences MCSER Publishing, Rome-Italy Vol 7 No 1 S1 January 2016. Doi:10.5901/mjss.2016.v7n1s1p40

Rozaki, Z. 2020. Covid-19, Agriculture and Food Security in Indonesia. Disampaikan pada Internasioanl Webinar "Southeast Asian Agriculture Post Covid-19 Pandmei:
Current and Future Perspectives" pada 11 Juli 2020.

Shakil, M.H., Tasnia, M., Munim, Z.H and Mehedi, M.H.K. (2014) Mushroom as a mechanism to alleviate poverty, unemployment and malnutrition. Asian Bus Rev 4(9):31-34.

Shwetha, V.K and Sudha, G.M. (2012). Ameliorative effect of Volvariella volvacea aqueous extract (Bulliard ex fries) singer on gentamicin induced renal damage. Int $\mathbf{J}$ Pharm Bio Sci 3(3): 105-117.

Sinaga, M.S. 2009. Jamur Merang dan Budidayanya. Jakarta: Penebar Swadaya.

Solovyev N, Prakash NT, Bhatia P, Prakash R, Drobyshev E, Michalke B (2018) Selenium-rich mushrooms cultivation on a wheat straw substrate from seleniferous area in Punjab, India. J Trace Elem Med Biol 50:362-366.

Sudha, A., Lakshmanan, $\mathrm{P}$ and Kalaiselvan, B. (2008) Antioxidant properties of paddy straw mushroom (Volvariella volvacea (bull. Ex Fr.)) sing. Int J Appl Agric Res 3:9-16.

Thiribhuvanamala G, Krishnamoorthy S, Manoranjitham K, Praksasm V, Krishnan S (2012) Improved techniques to enhance the yield of paddy straw mushroom (Volvariella volvacea) for commercial cultivation. Afr J Biotechnol 11(64):12740-12748.

Walde SG, Velu V, Jyothirmayi T, Math RG (2006) Effects of pretreatment and drying methods on dehydration of mushroom. J Food Eng 74:108115.

Zhang Y, Geng W, Shen Y, Wang Y, Dai YC (2014) Edible mushroom cultivation for food security and rural development in China: bioinnovation, technological 
dissemination and marketing. Sustainability 6(5):2961-2973.

Zikriyani H, Saskiawan I, Mangunwardoyo W (2018) Utilization of agricultural waste for cultivation of paddy straw mushrooms (Volvariella volvacea (bull.) singer 1951). Intl J Agric Technol 14(5):805-814. 